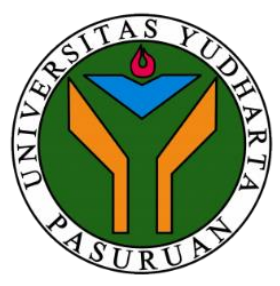

\title{
Penentuan Dosen Terbaik Menggunakan Metode Analytical Hierarchy Process (AHP) dan Technique For Order By Similarity To Ideal Solution (TOPSIS): Studi Kasus Akademi Teknologi Bogor
}

\author{
Istiqoomatun Nisaa ${ }^{1}$, Arief Wibowo ${ }^{2}$ \\ ${ }^{1,2}$ Fakultas Teknologi Informasi, Magister Ilmu Komputer, Universitas Budi Luhur \\ email: ${ }^{1} 1811600038 @$ student.budiluhur.ac.id, ${ }^{2}$ arief.wibowo@budiluhur.ac.id
}

\begin{tabular}{l}
\hline INFO ARTIKEL \\
\hline Sejarah Artikel: \\
Diterima 26 September 2020 \\
Direvisi - \\
Disetujui 24 Oktober 2020 \\
Dipublikasi 02 Desember 2020 \\
\hline Katakunci: \\
Penentuan Dosen Terbaik \\
Sistem Penunjang Keputusan \\
Analytical Hierarchy Process \\
Technique For Order By Similarity \\
To Ideal Solution
\end{tabular}

\begin{abstract}
ABSTRAK
Akademi Teknologi Bogor yang berdiri sejak tahun1997, berlokasi di Kota Bogor. Didukung 40 staf dosen. Dosen mempunyai kedudukan sebagai tenaga professional pada jenjang pendidikan tinggi yang diangkat sesuai dengan peraturan perundang-undangan. Dosen adalah tenaga pendidik yang memberikan sejumlah ilmu pengetahuan kepada anak didik di Perguruan Tinggi. Sistem penentuan dosen terbaik digunakan untuk mendukung kegiatan belajar dan mengajar dikampus agar terciptanya mahasiswa yang berkualitas dan kompeten di bidangnya. Hal ini untuk memenuhi kriteria dosen untuk memutuskan dosen yang dianggap terbaik. Proses penentuan dosen terbaik pada sistem yang berjalan saat ini masih memiliki kekurangan yaitu membutuhkan waktu yang lama untuk memproses data hasil kuesioner, sehingga keputusan yang didapat belum valid. Pada penelitian ini akan dibuat sebuah Sistem Pendukung Keputusan (SPK) dimana sistem ini dapat membantu seseorang mengambil keputusan yang akurat dan tepat sasaran. Adapun metode yang digunakan yaitu metode Analytical Hierarchy Process (AHP) untuk menghitung bobot setiap kriteria dan Technique For Order By Similarity To Ideal Solution (TOPSIS) untuk merangking alternatif berdasarkan setiap kriteria. Hasil penelitian ini adalah sebuah sistem yang mampu menghasilkan urutan perangkingan dalam penentuan dosen terbaik di Akademi Teknologi Bogor.
\end{abstract}

Keyword:
Selection of the Best Lecturer
Decision Support System
Analytical Hierarchy Process
Technique For Order By
Similarity To Ideal Solution
DOI Artikel:
10.35891/explorit.v12i2.2288

\section{ABSTRACT}

The Bogor Institute of Technology, which was founded in 1997, is located in the city of Bogor. Supported by 40 lecturers. Lecturers have a position as professional staff at the higher education level who are appointed in accordance with st(atutory regulations. Lecturers are educators who provide a number of knowledge to students in Higher Education. The system for determining the best lecturers is used to support teaching and learning activities at campus so that students who are qualified and competent in their fields are created. This is to meet the criteria for lecturers who decide which lecturer is considered the best. The process of determining the best lecturer in the current system still has shortcomings, namely it takes a long time to process the data from the questionnaire, so the decision is not valid. In this study, a Decision Support System (DSS) will be made where this system can help someone make accurate and right-on-target decisions. The method used is the Analytical Hierarchy Process (AHP) method to calculate the weight of each criterion and the Technique For Order By Similarity To Ideal Solution (TOPSIS) to rank alternatives based on each criterion. The result of this research is a system capable of producing a ranking order in determining the best lecturers at the Bogor Institute of Technology.

@ 2020 diterbitkan oleh Prodi Teknik Informatika Universitas Yudharta Pasuruan

\section{Pendahuluan}

Dosen adalah pendidik profesional dan ilmuwan dengan tugas utama mentransformasikan, mengembangkan dan menyebarluaskan ilmu pengetahuan, teknologi dan seni melalui pendidikan, penelitian, dan pengabdian kepada masyarakat. (Undang-undang RI No. 14 Tahun 2005 Tentang Guru dan Dosen). Pada pasal 51 Ayat (1) butir b, bahwa dosen berhak mendapatkan penghargaan sesuai dengan kinerja akademiknya. Pada setiap akhir semester Akademi Teknologi Bogor selalu memilih salah satu dosen terbaik, karena sudah selayaknya dosen diberikan penghargaan supaya lebih mendorong prestasi dosen secara efektif dan produktif, sehingga dapat mendorong tercapainya tujuan pengembangan sistem pendidikan perguruan tinggi, khususnya pembangunan nasional pada umumnya.

Pada pengolahan data untuk kebutuhan penilaian kinerja dosen, Akademi Teknologi Bogor masih menggunakan program aplikasi Microsoft Excel. Kuesioner penilaian diberikan kepada mahasiswa untuk diisi dan dikembalikan ke bagian akademik. Dalam hal ini tentu saja tidak efisien, memakan waktu cukup lama dan memungkinkan terjadinya human error. Penilaian dosen diberikan kepada mahasiswa, tidak dinilai oleh pihak kampus. Hal ini memiliki kerawanan, dimana penilaian secara subjektif dari mahasiswa. Selain itu penilaian Kinerja Dosen hanya mengambil salah satu dari kriteria Tridharma Perguruan Tinggi yaitu Pendidikan dan Pengajaran, sehingga pengajaran tidak menyeluruh dari seluruh aspek.

Berdasarkan permasalahan yang dihadapi, maka diperlukan sebuah Sistem Pendukung Keputusan. SPK merupakan salah satu cara yang digunakan untuk menyelesaikan persoalan yang tidak terstruktur sehingga dapat memberikan informasi yang bisa digunakan oleh para pengambil keputusan dalam membuat sebuah keputusan.

\section{Kajian Teori}

\subsection{Sistem Pendukung Keputusan}

Sistem pengambilan keputusan (SPK) adalah sistem informasi berbasis komputer untuk mendukung pihak manajamen untuk mengambil keputusan berdasarkan kriteria yang disusun dalam pengolahan data pengambilan keputusan dilakukan komputer. Pengambilan keputusan dengan menggunakan 
SPK maka keputusan yang diambil telah melalui proses pemilihan diantara beberapa alternatif yang tersedia sehingga keputusan yang diambil menjadi optimal. Sistem Pendukung Keputusan merupakan sebuah sistem yang dimaksudkan mendukung para pengambil keputusan manajerial dalam situasi keputusan semi-terstruktur.

Sistem pendukung keputusan (SPK) merupakan sebuah sistem yang memiliki kriteria sebagai berikut, (Turban, 2015) :

1. Penggunaan model, komunikasi antara pengambil keputusan dan sistem terjalin melalui model-model matematis, jadi pengambil keputusan bertanggung jawab membangun model matematis berdasarkan permasalahan yang dihadapinya.

2. Berbasis komputer, sistem ini mempertemukan penilaian manusia (pengambil keputusan) dengan informasi komputer. Informasi komputer ini dapat berasal dari perangkat lunak komputer yang merupakan implementasi dari metode numeris untuk permasalahan matematis yang bersangkutan.

3. Fleksibel, sistem harus dapat beradaptasi terhadap timbulnya perubahan pada permasalahan yang ada. Jadi pengambil keputusan harus dibolehkan untuk melakukan perubahan pada model yang telah diberikannya kepada sistem, ataupun memberikan model yang baru.

4. Interaktif dan mudah digunakan, pengambil keputusan bertanggung

Kemampuan sistem pendukung keputusan di antaranya sebagai berikut, (Turban, 2015):

1. Menunjang pembuatan keputusan manajemen dalam menangani masalah semi terstruktur.

2. Manajemen, mulai dari manajemen tingkat atas sampai manajemen tingkat dan tidak terstruktur.

3. Membantu manajer pada berbagai tingkatan bawah

4. Menunjang pembuatan keputusan secara kelompok dan perorangan.

5. Menunjang pembuatan keputusan yang saling bergantungan dan berurutan.

6. Menunjang tahap-tahap pembuatan keputusan antara lain intelligence, design, choice dan implementasi.

7. Menunjang berbagai bentuk proses pembuatan keputusan dan jenis keputusan.

8. Kemampuan untuk melakukan adaptasi setiap saat dan bersifat fleksibel.

\subsection{Analytical Hierarchy Process (AHP)}

Analitycal Hierarchy Process (AHP) merupakan salah satu metode dalam sistem pendukung keputusan yang menggunakan bobot kriteria dengan memilih alternatif terbaik dan digunakan untuk memecahkan suatu situasi yang komplek tidak terstruktur kedalam beberapa komponen dalam susunan yang hirarki, dengan memberi nilai subjektif tentang pentingnya setiap variabel secara relatif, dan menetapkan variabel mana yang memiliki prioritas paling tinggi guna mempengaruhi hasil pada situasi tersebut. Model pendukung keputusan ini akan menguraikan masalah multi faktor atau multi kriteria yang kompleks menjadi suatu hirarki, menurut (Saaty, 2016).

Untuk menentukan solusi, Metode AHP memerlukan point-point penilaian dari masing-masing kuesioner yang ditanyakan. Selain itu AHP dalam menentukan kriteria-kriteria yang bersifat multikriteria. Berikut Struktur Hierarki Metode AHP:

1. Dekomposisi

Dekomposisi adalah proses menganalisa permasalahan rill dalam struktur hierarki atas unsur-unsur pendukungnya. Struktur hierarki secara umum dalam metode AHPdapat dilihat pada gambar 2.1 dengan tujuan adalah mencari Dosen dengan kompetensi terbaik.

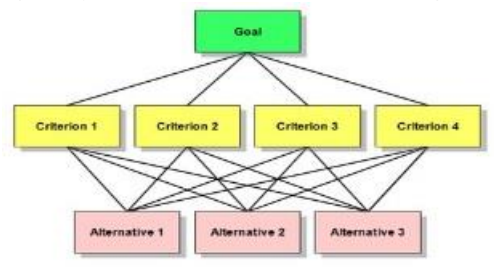

Gambar 2.1 Sturktur Hierarki Metode AHP

2. Comperative Judgment (Perbandingan Penilaian)

Perbandingan penilaian adalah membuat suatu penilaian tentang kepentingan relatif antara dua elemen pada suatu tingkat tertentu yang disajikan dalam bentuk matriks dengan menggunakan skala prioritas. Contoh perbandingan dapat dilihat dari Tabel 2.1 Matriks perbandingan berpasangan.

Tabel 2.1 Matriks perbandingan berpasangan.

\begin{tabular}{|l|l|l|l|}
\hline & K1 & K2 & K3 \\
\hline K1 & 1 & & \\
\hline K2 & & 1 & \\
\hline K3 & & & 1 \\
\hline
\end{tabular}

Pertanyaan yang diajukan dalam penyusunan skala prioritas adalah:

a. Elemen mana yang lebih (penting/disukai/mungkin/....)?

b. Berapa kali lebih (penting/disukai/mungkin/....)?

Penyusunan skala Perbandingan Saaty ditunjukkan pada Tabel 2.2.

Tabel 2.2 Skala Perbandingan Saaty.

\begin{tabular}{|l|l|}
\hline Nilai & Keterangan \\
\hline 1 & A sama pentting (Equal) dengan B \\
\hline 3 & A sedikit lebih penting (Moderate) dari B \\
\hline 5 & A jelas penting (Strong) B \\
\hline 7 & A sangat jelas Penting (Very Strong) dari B \\
\hline 9 & A mutlak lebih penting (Extreme) dari B \\
\hline $2,4,6,8$ & Apabila ragu-ragu antara 2 nilai yang berdekatan \\
\hline $1 /(1-9)$ & Kebalikan nilai tingkat kepentingan dari skala 1-9 \\
\hline
\end{tabular}

3. Synthesis of Priority (Sintesa Prioritas)

Dalam sintesa prioritas, dikenal konsep prioritas lokal dan global. Prioritas lokal (Local Priority) diperoleh dari perhitungan nilai eigen vektor pada setiap elemen matriks perbandingan berpasangan pada tingkatan yang sama. Prioritas global (Priority Global) diperoleh dari perkalian prioritas lokal untuk setiap perbandingan berpasangan dengan nilai eigen vektor tingkat diatasnya.

4. Logical Consitency (Konsistensi Logis)

Konsistensi memiliki dua makna. Pertama, objek -objek yang serupa bisa dikelompokkan sesuai dengan keseragaman dan relevansi. Kedua, menyangkut tingkat hubungan antar objek yang didasarkan pada kriteria tertentu. 
Pada proses pengambilan keputusan, sangat penting untuk mengetahui seberapa baik konsistensi yang ada. Metode AHP mempertimbangkan suatu nilai konsistensi yang logis dalam penilaian yang digunakan untuk menentukan suatu prioritas. Nilai konsistensi dihitung berdasarkan persamaan dan tabel 2.3 berikut ini :

$\mathrm{CI}=\frac{\lambda m a k s-n}{n-1}$

Ket :

$\mathrm{n}=$ banyaknya kriteria

$\mathrm{CI}=$ indek Konsistensi (Consistency Index)

$\mathrm{CR}=\frac{C I}{I R}$

Ket :

$\mathrm{CR}=$ Rasio Konsistensi

IR = Index Rasio (Nilai Indek Rasio Tergantung pada ukuran matriks)

Jika nilai $\mathrm{CR} \leq 0,1$, maka hasil perhitungan data dapat diterima, sebaliknya jika nilai yang $\mathrm{CR}>0,1$ makahasil preferensi pembobotan tidak dapat diterima, sehingga perbandingan berpasangan harus diulang.

Tabel 2.3 Nilai Indeks Random

\begin{tabular}{|l|l|l|l|l|l|l|l|l|}
\hline $\mathrm{n}$ & 1 & 2 & 3 & 4 & 5 & 6 & 7 & 8 \\
\hline RI & 0.00 & 0.00 & 0.58 & 0.90 & 1.12 & 1.24 & 1.32 & 1.41 \\
\hline $\mathrm{N}$ & 9 & 10 & 11 & 12 & 13 & 14 & 15 & \\
\hline $\mathrm{RI}$ & 1.45 & 1.49 & 1.51 & 1.48 & 1.56 & 1.57 & 1.59 & \\
\hline
\end{tabular}

\subsection{Technique for Order Preference by Similarity to Ideal Solution (TOPSIS)}

Metode Topsis merupakan sistem pengambilan keputusan yang didasarkan pada multikriteria dengan prinsip alternatif yang terpilih adalah alternatif terbaik dengan jarak terdekat dari solusi tidak hanya mempunyai jarak terdekat dari solusi ideal positif, namun juga memiliki jarak terjauh dari solusi ideal negatif dari sudut pandang geometris dengan menggunakan jarak Euclidean untuk menentukan kedekatan relatif dari suatu alternatif dengan solusi optimal. Solusi ideal positif didefinisikan sebagai jumlah dari seluruh nilai terbaik yang dapat dicapai untuk setiap atribut, sedangkan solusi negatifideal terdiri dari seluruh nilai terburuk yang dicapai untuk setiap atribut.

\subsection{Langkah-Langkah Metode TOPSIS}

Langkah-langkah yang dilakukan dalam menyelesaikan suatu permasalahan menggunakan metode TOPSIS adalah sebagai berikut (Kusumadewi dkk., 2006)

1. Menggambarkan alternatif $(\mathrm{m})$ dan kriteria $(\mathrm{n})$ ke dalam sebuah matriks, dimana Xij adalah pengukuran pilihan dari alternatif ke-i dan kriteria ke-j Matriks ini dapat dilihat pada persamaan 2.7

$$
\mathrm{D}=\left[\begin{array}{lll}
X_{11} & X_{12} & X_{13} \\
X_{21} & X_{22} & X_{23} \\
X_{i 1} & X_{i 2} & X_{i 3}
\end{array}\right] \ldots
$$

2. Membuat matriks R yaitu matriks keputusan ternormalisasi Setiap normalisasi dari nilai rij dapat dilakukan dengan perhitungan menggunakan persamaan 2.8

$$
r_{i j}=\frac{X_{i j}}{\sqrt{\sum_{i=1}^{m} X_{i j}}} \ldots \ldots
$$

3. Membuat pembobotan pada matriks yang telah dinormalisasi Setelah dinormalisasi, setiap kolom pada matriks R dikalikan dengan bobot-bobot (wj) untuk menghasilkan matriks pada persamaan 2.9

$$
\mathrm{D}=\left[\begin{array}{ccc}
W_{1} r_{11} & W_{1} r_{12} & W_{n} r_{n} \\
W_{2} r_{21} & \ldots & \ldots \\
W_{j} r_{m 1} & W_{j} r_{m 2} & W_{j} r_{m m}
\end{array}\right] \ldots
$$

4. Menentukan nilai solusi ideal positif dan solusi ideal negatif. Solusi ideal dinotasikan A+, sedangkan solusi ideal negatif dinotasikan A-. Persamaan untuk menentukan solusi ideal dapat dilihat pada persamaan 2.10

$A+\quad=\left\{\left(\max V_{i j} \mid j \in J\right),\left(\min V_{i j} \mid j € j{ }^{\prime}\right)\right.$,

$\left.\mathrm{i}=1,2,3, \ldots, \mathrm{m}\}=\mathrm{V}_{1}+\mathrm{V}_{2}+, \ldots, \mathrm{V}_{\mathrm{n}}+\right\}$

A- $\quad=\left\{\left(\max V_{i j} \mid j \in J\right),\left(\min V_{i j} \mid j € j j^{\prime}\right)\right.$,

$\left.\mathrm{i}=1,2,3, \ldots, \mathrm{m}\}=\mathrm{V}_{1}-\mathrm{V}_{2}-, \ldots, \mathrm{V}_{\mathrm{n}}-\right\} \ldots \ldots \ldots . . .(2.10)$

$\mathbf{J}=\{\mathrm{j}=1,2,3, \ldots, \mathrm{n}$ dan $\mathrm{j}$ merupakan benefit criteria $\}$

J' $\quad=\{\mathrm{j}=1,2,3, \ldots, \mathrm{n}$ dan $\mathrm{j}$ merupakan cost criteria $\}$

5. Menghitung separation measure. Separation measure ini merupakan pengukuran jarak dari suatu alternatif ke solusi ideal positif dan solusi ideal negatif.

- Perhitungan solusi ideal positif dapat dilihat pada persamaan 2.11.

Dengan $i=1,2,3, \ldots, \mathrm{m}$

$$
\mathrm{s}_{\mathrm{i}^{+}}=\sqrt{\sum_{i=1}^{n}\left(V_{i j}-V_{j}+\right)^{2} \ldots \ldots}
$$

- Perhitungan solusi ideal negatif dapat dilihat pada persamaan 2.12 :

Dengan $i=1,2,3, \ldots, \mathrm{m}$

$$
\mathrm{s}_{\mathrm{i}}{ }^{+}=\sqrt{\sum_{i=1}^{n}\left(V_{i j}-V_{j}-\right)^{2} \ldots \ldots}
$$

6. Menghitung nilai preferensi untuk setiap alternatif. Untuk menentukan ranking tiap-tiap alternatif yang ada maka perlu dihitung terlebih dahulu nilai preferensi dari tiap alternatif. Perhitungan nilai preferensi dapat dilihat melalui persamaan 2.13 . 


$\left.\mathrm{C}_{\mathrm{i}^{+}}=\begin{array}{c}S_{i^{-}} \\ \cdot \\ S_{i}+S_{i^{-}}\end{array}\right] \ldots \ldots(2.13)$
Dimana $0<\mathrm{C}_{\mathrm{i}}=<1$ dan $\mathrm{i}=1,2,3, \ldots, \mathrm{m}$

\subsection{Penentuan Dosen Terbaik}

Penentuan Dosen Terbaik berdasarkan pada penilaian kinerja.

a. Pengertian Penilaian Kinerja Dosen Terbaik

Penilaian kinerja dosen terdiri dari beberapa tahapan, menurut Gary (1997:3) penilaian kinerja terdiri dari tiga langkah, yaitu: mendefinisikan pekerjaan, menilai kinerja dan memberikan umpan balik.

Dalam penelenggaraan pendidikan, salah satu upaya untuk meningkatan kualitas proses belajar mengajar adalah meningkatkan kinerja dosen (P.R Indonesia, Peraturan Pemerintah Republik Indonesia No. 37 tahun 2009 tentang Dosen, Jakarta).

Penilaian kinerja membutuhkan standar yang jelas yang dijadikan tolak ukur terhadap kinerja yang akan diukur. Standar yang dibuat harus berhubungan dengan jenis pekerjaan yang akan diukur dan hasil yang diharapkan. Ada empat hal yang harus diperhatikan dalam menyusun standar penilaian kinerja yaitu validity, agreement, realism, dan objectivity (G.B. Brumbach,1998).

\section{b. Tujuan Menentukan Dosen Terbaik}

Berdasarkan undang-undang RI No. 14 Tahun 2005 tentang Guru dan Dosen, bahwa dosen berhak mendapatkan promosi dan penghargaan sesuai dengan kinerja akademiknya.

\section{c. Proses Penilaian Kinerja Dosen}

Menurut Marwansyah dan Mukaram (200:108) ada liam langkah dalam proses Penilaian Unjuk Kerja (PUK), Yaitu:

1. Mengidentifikasi tujuan spesifikasi penilaian unit kerja.

2. Menentukan tugas-tugas yang harus dijalankan dalam suatu pekerjaan (analisa jabatan).

3. Memeriksa tugas-tugas yang dijalani.

4. Menilai unjuk kerja.

5. Membicarakan hasil penilaian dengan karyawan.

\section{d. Kriteria Penilaian Kinerja Dosen}

Kriteria dosen yang digunakan pada penelitian ini sebagai berikut:

1. Kurikulum

2. Perangkat Pembelajaran (RPP/RPS)

3. Materi Bahan Ajar

4. Media Pembelajaran

5. Kehadiran Dosen

\subsection{Konsep Dasar Model Prototype}

Prototype didefinisikan sebagai alat yang memberikan ide bagi pembuat maupun pemakai potensial tentang cara sistem berfungsi dalam bentuk lengkapnya, dan proses untuk menghasilkan prototype disebut prototyping.

Prototyping adalah proses pembuatan model sederhana perangkat lunak yang mengijinkan pengguna memiliki gambaran dasar tentang program serta melakukan pengujian awal.

\subsection{UAT (User Acceptance Testing)}

User Acceptance Test (UAT) atau Uji Penentuan Dosen Terbaik adalah suatu proses pengujian oleh pengguna yang dimaksudkan untuk menghasilkan dokumen yang dijadikan bukti bahwa software yang telah dikembangkan telah dapat diterima oleh pengguna, apabila hasil pengujian (testing) sudah bisa dianggap memenuhi kebutuhan dari pengguna. Proses UAT didasarkan pada dokumen requirement yang disepakati bersama. Dokumen requirement adalah dokumen yang berisi lingkup pekerjaan software yang harus dikembangkan, dengan demikian maka dokumen ini semestinya menjadi acuan untuk pengujian. Proses dalam UAT adalah pemeriksaan dan pengujian terhadap hasil pekerjaan. Diperiksa apakah item-item yang ada dalam dokumen requirement sudah ada dalam software yang diuji atau tidak. Diuji apakah semua item yang telah ada telah dapat memenuhi kebutuhan penggunanya.

\section{Metodologi Penelitian}

\subsection{Metode Penelitian}

Metode penelitian yang digunakan dalam Research and Development ( $\&$ D), dimana metode ini digunakan untuk menghasilkan produk tertentu dan mengkaji kefektifan produk tersebut. Merode R \& D merupakan suatu proses atau langkah-langkah untuk mengembangkan produk baru atau menyempurnakan produk yang sudah ada. Produk dalam konteks ini adalah perangkat lunak (software) untuk proses penilaian pengajaran yang dilakukan oleh dosen, dengan sistem aplikasi yang dibangun menggunakan metode Technique for Order by Similarity to Ideal Solution (TOPSIS) dan Analytical Hierarchy Process (AHP).

\subsection{Langkah-langkah Penelitian}

Langkah-langkah penelitian harus dilaksanakan secara urut dan terstruktur sesuai standar aturan masing-masing instansi. Dengan langkah yang urut dan struktur ini harus diselesaikan mulai dari awal hingga akhir proses. Selain menjalankan prosedur yang telah dibuat, wawancara mengumpulkan data yang digunakan dalam memecahkan masalah tersebut. Dan setiap langkah-langkah penelitian perlu didokumentasikan. Langkah-langkah penelitian ini sebagai berikut: 


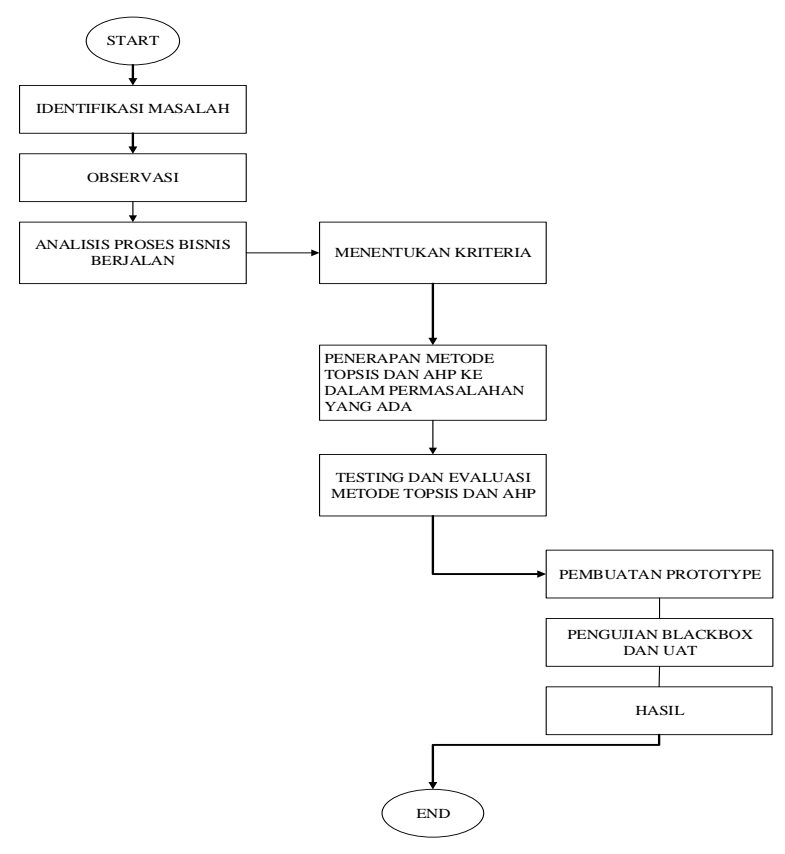

Gambar 3. 2 Langkah-langkah Penelitian

\section{$4 \quad$ Hasil Uji Coba Dan Pembahasan}

4.1 Analisis Masalah

Permasalahan yang terjadi di Akademi Teknologi Bogor yaitu penilaian proses belajar sistem di Akademi Teknologi Bogor dilakukan berdasarkan hasil pengisian kuesioner oleh mahasiswa dan wawancara kepada kepala Wakil Direktur I bagian Akademik. Proses perhitungan penilaian proses belajar masih manual menggunakan excel.

\subsection{Analisa Proses Berjalan}

Penilaian Proses belajar sistem di Akademi Teknologi Bogor dilakukan berdasarkan hasil pengisian kuesioner oleh mahasiswa. Instrument pada kuesioner belum diberi bobot tingkat kepentingan. Langkah- langkah pemecahan masalah dalam pengembangan sistem yang akan dibuat, yaitu: perencanaan sistem, menganalisis sistem, merancang sistem dan implementasi sistem.

\subsection{Penentuan Kriteria}

Kriteria yang digunakan untuk perangkingan alternatif penilaian proses belajar dilakukan melalui wawancara dengan dosen yang dilakukan oleh Direktur Akatek Bogor serta melalui Studi Pustaka. Maka diperoleh 5 kriteria yaitu: Kehadiran Dosen, Perangkat Pembelajaran, Materi bahan ajar dan Media Pembelajaran, Kegiatan belajar mengajar berdasarkan kurikulum.

Tabel 4.1 Data Kriteria

\begin{tabular}{|c|l|}
\hline Kode & \multicolumn{1}{|c|}{ Ketentuan Kriteria } \\
\hline C1 & Kurikulum \\
\hline C2 & Perangkat Pembelajaran (RPP/RPS) \\
\hline C3 & Materi Bahan Ajar \\
\hline C4 & Media Pembelajaran \\
\hline C5 & Kehadiran Dosen \\
\hline
\end{tabular}

Tabel 4.2 Penilaian Bobot Kriteria Metode TOPSIS

\begin{tabular}{|c|l|c|}
\hline Kode & \multicolumn{1}{|c|}{ Ketentuan Kriteria } & Nilai \\
\hline C1 & Kurikulum & 5 \\
\hline C2 & Perangkat Pembelajaran (RPP/RPS) & 4 \\
\hline C3 & Materi Bahan Ajar & 3 \\
\hline C4 & Media Pembelajaran & 2 \\
\hline C5 & Kehadiran Dosen & 1 \\
\hline
\end{tabular}

4.3.1 Alternatif

Berikut adalah tabel alternatif sesuai dengan data nama dosen di Akademi Teknologi Bogor Sebagai data nama dosen untuk dapat mengajar kembali pada semester berikutnya.

Tabel 4.3 Data Alternatif

\begin{tabular}{|l|c|l|}
\hline No & NIP & \multicolumn{1}{|c|}{ NAMA } \\
\hline 1 & 55460128 & Nicky Yongkimandalan,ST.,MT \\
\hline 2 & 55460135 & H. Mulyana,ST.,MT \\
\hline 3 & 55460254 & Ardi Faisal,ST \\
\hline 4 & 55460256 & Annas Rifai,S.Kom \\
\hline 5 & 55460258 & Nurhidayat,ST.,MT \\
\hline
\end{tabular}

\subsection{Metode AHP}

Dalam pembobotan kriteria penilaian proses belajar, dipilih responden yang memiliki jabatan Direktur pada Akademi Teknologi Bogor merupakan tempat penulis dalam melakukan penelitian. Berikut detail respondens dalam pembobotan kriteria: 
Tabel 4.4 Responden Kriteria

\begin{tabular}{|c|c|c|}
\hline No & Responden & Posisi \\
\hline 1 & Lilis Cucu S & Direktur \\
\hline
\end{tabular}

Selanjutnya digunakan metode AHP untuk mendapatkan nilai bobot masing-masing kriteria yang akan dijadikan tolak ukur penilaian. Berikut merupakan hasil dari perbandingan berpasangan setiap alternatif masing-masing responden.

\subsubsection{Membuat Matriks Perbandingan Berpasangan}

Pada metode ini akan dibuat matriks perbandingan berpasangan yang akan diambil dari nilai tabel kriteria. Dari kuesioner yang dibagi oleh Bagian Akademik. Hasil matriks perbandingan berpasangan bisa dilihat pada persamaan tabel 2.1 dan tabel 4.5.

Tabel 4.5 Matriks Perbandingan Berpasangan

\begin{tabular}{|c|c|c|c|c|c|}
\hline Kriteria & Kurikulum & $\begin{array}{c}\text { Perangkat } \\
\text { Pembelajaran } \\
\text { (RPP/RPS) }\end{array}$ & $\begin{array}{c}\text { Materi } \\
\text { Bahan } \\
\text { Ajar }\end{array}$ & $\begin{array}{c}\text { Metode } \\
\text { Pembelajaran }\end{array}$ & $\begin{array}{c}\text { Kehadiran } \\
\text { Dosen }\end{array}$ \\
\hline C1 & 1 & $1 / 4$ & $1 / 3$ & 3 & 2 \\
\hline C2 & 4 & 1 & $1 / 2$ & 2 & 4 \\
\hline C3 & 3 & 2 & 1 & 4 & 3 \\
\hline C4 & $1 / 3$ & $1 / 2$ & $1 / 4$ & 1 & 2 \\
\hline C5 & $1 / 2$ & $1 / 4$ & $1 / 3$ & $1 / 2$ & 1 \\
\hline
\end{tabular}

\subsubsection{Normalisasi Matriks Nilai Kriteria}

Kemudian dilakukan normalisasi matriks nilai kriteria dari hasil matriks perbandingan berpasangan dari kriterianya. Nilai bobot prioritas selanjutnya akan diuji konsistensinya sebelum digunakan dalam perangkingan dengan Metode TOPSIS. Penjumlahan Matriks tiap kolom dapat dilihat pada tabel 4.6.

Tabel 4.6 Penjumlahan Matriks Tiap Kolom

\begin{tabular}{|c|c|c|c|c|c|}
\hline Kriteria & Kurikulum & $\begin{array}{c}\text { Perangkat } \\
\text { Pembelajaran }\end{array}$ & $\begin{array}{c}\text { Materi } \\
\text { Bahan } \\
\text { Ajar }\end{array}$ & $\begin{array}{c}\text { Metode } \\
\text { Pembelajaran }\end{array}$ & $\begin{array}{c}\text { Kehadiran } \\
\text { Dosen }\end{array}$ \\
\hline C1 & 1.0000 & 0.2500 & 0.3333 & 3.0000 & 2.0000 \\
\hline C2 & 4.0000 & 1.0000 & 0.5000 & 2.0000 & 4.0000 \\
\hline C3 & 3.0000 & 2.0000 & 1.0000 & 4.0000 & 3.0000 \\
\hline C4 & 0.3333 & 0.5000 & 0.2500 & 1.0000 & 2.0000 \\
\hline C5 & 0.5000 & 0.2500 & 0.3333 & 0.5000 & 1.0000 \\
\hline Jumlah & 8.8333 & 4.0000 & 2.4166 & 10.5000 & 12.0000 \\
\hline
\end{tabular}

Dari matriks pembobotan kriteria, maka dapat dihitung nilai eigen, lamda maksimum, dan CR. Sebelum menghitung nilai eigen, dicari nilai perbandingan pada tiap kolom dibagi dengan jumlah kolomnya, seperti di bawah ini pada tabel 4.7.

Tabel 4.7 Nilai Perbandingan Tiap Kolom Dibagi Jumlah Kolom

\begin{tabular}{|c|c|c|c|c|c|}
\hline Kriteria & Kurikulum & Perangkat Pembelajaran & Materi Bahan Ajar & Metode Pembelajaran & Kehadiran Dosen \\
\hline C1 & 0.1132 & 0.0625 & 0.1379 & 0.2857 & 0.1667 \\
\hline C2 & 0.4528 & 0.2500 & 0.2069 & 0.1905 & 0.3333 \\
\hline C3 & 0.3396 & 0.5000 & 0.4138 & 0.3810 & 0.2500 \\
\hline C4 & 0.0377 & 0.1250 & 0.1035 & 0.0952 & 0.1667 \\
\hline C5 & 0.0566 & 0.0625 & 0.1379 & 0.0476 & 0.0833 \\
\hline Jumlah & 1,0000 & 1,0000 & 1,0000 & 1,0000 & 1,0000 \\
\hline
\end{tabular}

\subsubsection{Nilai Rata-rata Matriks tiap baris}

Setelah dilakukan normalisasi matriks nilai kriteria maka menghitung nilai rata-rata matriks tiap baris pada sub kriteria. Untuk nilai rata-rata tiap matriks dapat dilihat pada tabel 4.8 .

Tabel 4.8 Rata-rata Nilai Matriks Tiap Baris

\begin{tabular}{|c|c|c|c|c|c|c|}
\hline Kriteria & Kurikulum & $\begin{array}{c}\text { Perangkat } \\
\text { Pembelajaran }\end{array}$ & $\begin{array}{c}\text { Materi } \\
\text { Bahan } \\
\text { Ajar }\end{array}$ & $\begin{array}{c}\text { Metode } \\
\text { Pembelajaran }\end{array}$ & $\begin{array}{c}\text { Kehadiran } \\
\text { Dosen }\end{array}$ & Jumlah \\
\hline C1 & 0.1132 & 0.0625 & 0.1379 & 0.2857 & 0.1667 & 0,7660 \\
\hline C2 & 0.4528 & 0.2500 & 0.2069 & 0.1905 & 0.3333 & 1,4335 \\
\hline C3 & 0.3396 & 0.5000 & 0.4138 & 0.3810 & 0.2500 & 1,8844 \\
\hline C4 & 0.0377 & 0.1250 & 0.1035 & 0.0952 & 0.1667 & 0,5281 \\
\hline C5 & 0.0566 & 0.0625 & 0.1379 & 0.0476 & 0.0833 & 0,3880 \\
\hline Jumlah & 1,0000 & 1,0000 & 1,0000 & 1,0000 & 1,0000 & 5,0000 \\
\hline
\end{tabular}

\subsubsection{Nilai Eigen}

Setelah dilakukan normalisasi matriks nilai kriteria maka langkah selanjutnya adalah menghitung nilai eigen dan perhitungan lamda maksimum pada sub kriteteria dan dan perhitungan nilai eigen dan perhitungan lamda maksimum dapat dilihat pada tabel 4.9. 
Tabel 4.9 Nilai Eigen

\begin{tabular}{|c|c|c|c|c|c|c|}
\hline Kriteria & Kurikulum & $\begin{array}{c}\text { Perangkat } \\
\text { Pembelajaran }\end{array}$ & $\begin{array}{c}\text { Materi } \\
\text { Bahan Ajar }\end{array}$ & $\begin{array}{c}\text { Metode } \\
\text { Pembelajaran }\end{array}$ & $\begin{array}{c}\text { Kehadiran } \\
\text { Dosen }\end{array}$ & $\begin{array}{c}\text { Nilai } \\
\text { Eigen }\end{array}$ \\
\hline C1 & 0.1132 & 0.0625 & 0.1379 & 0.2857 & 0.1667 & 0,1532 \\
\hline C2 & 0.4528 & 0.2500 & 0.2069 & 0.1905 & 0.3333 & 0,2867 \\
\hline C3 & 0.3396 & 0.5000 & 0.4138 & 0.3810 & 0.2500 & 0,3769 \\
\hline C4 & 0.0377 & 0.1250 & 0.1035 & 0.0952 & 0.1667 & 0,1056 \\
\hline C5 & 0.0566 & 0.0625 & 0.1379 & 0.0476 & 0.0833 & 0,0776 \\
\hline Jumlah & 1,0000 & 1,0000 & 1,0000 & 1,0000 & 1,0000 & 1,0000 \\
\hline
\end{tabular}

Untuk itu diperlukan melakukan perhitungan $\lambda$ maksimum terlebih dahulu yang didapat dari total matriks sebelum dinormalisasi (tabel 4.9) dengan nilai eigen vektor utama, berikut detail hasil perhitungan tersebut pada tabel 4.10.

Tabel 4.10 Perhitungan Lambda Maksimum

\begin{tabular}{|l|c|c|c|l|}
\hline \multicolumn{1}{|c|}{ Kriteria } & Nilai Eigen & Total Matrik & $\begin{array}{c}\text { Nilai Eigen X } \\
\text { Total Matrik }\end{array}$ & \multicolumn{1}{|c|}{ Kriteria } \\
\hline Kurikulum & 0,1532 & 8,83330 & 1,353279179 & Kurikulum \\
\hline Perangkat Pembelajaran & 0,2867 & 4,0000 & 1,146834945 & Perangkat Pembelajaran \\
\hline Materi Bahan Ajar & 0,3769 & 2,4166 & 0,910758939 & Materi Bahan Ajar \\
\hline Metose Pembelajaran & 0,1056 & 10,5000 & 1,10898503 & Metose Pembelajaran \\
\hline Kehadiran Dosen & 0,0776 & 12,0000 & 0,931145794 & Kehadiran Dosen \\
\hline Lamda Maksimum & & 5,4509 & \\
\hline
\end{tabular}

Uji batas ketidak konsistenan yang diterapkan oleh Saaty, pengujian diukur menggunakan nilai CR (Consistency Ratio), yaitu perbandingan antara nilai CI dan RI, dimana nilai RI (Random Index) dapat dilihat pada tabel Random Index yang telah dijelaskan pada bab sebelumnya. Apabila nilai CR lebih kecil dari $10 \%(0,1)$ maka ketidak konsistenan pendapat masih dapat diterima. Sehingga didapatkan nilai CR yaitu :

$$
\begin{aligned}
C R & =\frac{0,1127}{1,12} \\
& =0,1006
\end{aligned}
$$

Hasil CR $<0.1$ maka dinyatakan konsisten dan dapat diterima.

\subsection{Metode TOPSIS}

Metode TOPSIS digunakan untuk perangkingan Asuransi dengan nilai yang diberikan untuk masing masing kriteria sudah ditentukan berdasarkan hasil wawancara, bobot prioritas juga didapatkan dari perhitungan sebelum nya melalui metode AHP.

\subsubsection{Perangkingan Alternatif dengan metode TOPSIS}

Metode TOPSIS menggunakan prinsip bahwa alternatif yang terpilih harus mempunyai jarak terdekat dari solusi ideal positif dan mempunyai jarak terjauh dari solusi ideal negatif. Pilihan akan diurutkan berdasarkan nilai sehingga alternatif yang memiliki jarak terpendek dengan solusi ideal positif adalah alternatif terbaik. Dengan demikian alternatif yang memiliki nilai besar itulah yang lebih baik untuk di pilih.

\section{Tabel 4.11 Data Matriks Nilai Alternatif}

\begin{tabular}{|l|c|c|c|c|c|}
\hline \multicolumn{1}{|c|}{ Kode } & Kurikulum & $\begin{array}{c}\text { Perangkat } \\
\text { Pembelajaran }\end{array}$ & $\begin{array}{c}\text { Materi } \\
\text { Bahan Ajar }\end{array}$ & $\begin{array}{c}\text { Metode } \\
\text { Pembelajaran }\end{array}$ & $\begin{array}{c}\text { Kehadiran } \\
\text { Dosen }\end{array}$ \\
\hline Nicky & 5 & 5 & 4 & 4 & 5 \\
\hline Mulyana & 4 & 3 & 3 & 3 & 4 \\
\hline Ardi & 5 & 3 & 4 & 3 & 4 \\
\hline Annas & 4 & 4 & 3 & 4 & 5 \\
\hline Nurhidayat & 5 & 4 & 4 & 4 & 5 \\
\hline
\end{tabular}

\subsubsection{Penilaian Kriteria Masing-masing Alternatif}

Nilai matriks ternormalisasi diambil dari data penilaian kriteria masing-alternatif dan diproses menggunakan rumus persamaan 2.7 dan tabel 4.12 .

Tabel 4.12 Nilai Normalisasi

\begin{tabular}{|l|l|l|l|l|l|l|l|l|l|}
\hline R11 & 0.4834 & R21 & 0.5774 & R31 & 0.4924 & R41 & 0.4924 & R51 & 0.4834 \\
\hline R12 & 0.3867 & R22 & 0.3464 & R32 & 0.3693 & R42 & 0.3693 & R52 & 0.3867 \\
\hline R13 & 0.4834 & R23 & 0.3464 & R33 & 0.4924 & R43 & 0.3693 & R53 & 0.3867 \\
\hline R14 & 0.3867 & R24 & 0.4619 & R34 & 0.3693 & R44 & 0.4924 & R54 & 0.4834 \\
\hline R15 & 0.4834 & R25 & 0.4619 & R35 & 0.4924 & R45 & 0.4924 & R55 & 0.4834 \\
\hline
\end{tabular}

Langkah selanjutnya adalah menentukan nilai matriks ternormalisasi terbobot dengan cara mengalikan tiap elemen dengan bobot kriteria masing-masing yang telah didapat dari perhitungan menggunakan metode AHP seperti yang telah dijelaskan sebelumnya dengan rumus persamaan 2.8 dan dapat lihat pada tabel 4.13 .

Tabel 4.13 Nilai Bobot Kriteria

\begin{tabular}{|l|l|}
\hline Kriteria & Bobot \\
\hline Kurikulum & 0,1532 \\
\hline Perangkat pembelajaran & 0,2867 \\
\hline Materi Bahan Ajar & 0,3769 \\
\hline Metode Pembelajran & 0,1056 \\
\hline Kehadiaran Dosen & 0,0776 \\
\hline
\end{tabular}


Tabel 4.14 Normalisasi Terbobot

\begin{tabular}{|c|c|c|c|c|c|c|c|c|c|}
\hline R11 & 0,0741 & R21 & 0,1655 & R31 & 0,1856 & R41 & 0,052 & R51 & 0,0375 \\
\hline R12 & 0,0592 & R22 & 0,0993 & R32 & 0,1392 & R42 & 0,039 & R52 & 0,03 \\
\hline R13 & 0,0741 & R23 & 0,0993 & R33 & 0,1856 & R43 & 0,039 & R53 & 0,03 \\
\hline R14 & 0,0592 & R24 & 0,1324 & R34 & 0,1392 & R44 & 0,052 & R54 & 0,0375 \\
\hline R15 & 0,0741 & R25 & 0,1324 & R35 & 0,1856 & R45 & 0,052 & R55 & 0,0375 \\
\hline
\end{tabular}

1. Mengidentifikasi solusi ideal positif dan solusi ideal negatif

Solusi ideal positif $(\mathrm{A}+)$ diperoleh dengan mencari nilai maksimal dari nilai normalisasi terbobot jika atributnya adalah atribut keuntungan (benefit) dan mencari nilai minimal dari nilai normalisasi terbobot jika atributnya adalah atribut biaya (cost).

Solusi ideal negatif (A-) diperoleh dengan mencari nilai minimal dari nilai normalisasi terbobot jika atributnya adalah atribut keuntungan (benefit) dan menjadi nilai maksimal dari nilai normalisasi terbobot jika atributnya adalah atribut keuntungan (benefit) dan menjadi nilai maksimal dari nilai normalisasi terbobot jika atributnya adalah atribut biaya (cost). Menentukan Solusi Ideal Positif (A+) dan Matriks Ideal Negatif (A-). Rumus Persamaan 2.10 dan tabel 4.15

\section{Tabel 4.15 Nilai Solusi Ideal Positif dan Solusi Ideal Negatif}

\begin{tabular}{|c|c|c|}
\hline Kode & Nilai Max & Nilai Min \\
\hline C1 & 0.0741 & 0.0592 \\
\hline C2 & 0.1655 & 0.0993 \\
\hline C 3 & 0.1856 & 0.1392 \\
\hline C4 & 0.052 & 0.039 \\
\hline C5 & 0.0375 & 0.03 \\
\hline
\end{tabular}

2. Menghitung jarak antara nilai setiap alternatif dengan matriks solusi ideal positif dan matriks solusi ideal negatif. Jarak antara alternatif dengan solusi ideal positif digunakan pada rumus persamaan 2.11 dan 2.12 dan tabel 4.16 .

Tabel 4.16 Nilai Jarak Ideal Positif dan Jarak Ideal Negatif

\begin{tabular}{|c|c|c|}
\hline Alternatif & D+ & D- \\
\hline D1 & 0 & 0.0836 \\
\hline D2 & 0.0836 & 0 \\
\hline D3 & 0.0679 & 0.0487 \\
\hline D4 & 0.0589 & 0.0363 \\
\hline D5 & 0.0331 & 0.0608 \\
\hline
\end{tabular}

3. Menentukan nilai kedekatan setiap alternatif terhadap solusi ideal nilai preferensi, Nilai preferensi (V) untuk setiap alternatif digunakan pada persamaan rumus 2.13 dan tabel 4.17 .

Tabel 4.17 Alternatif Ranking

\begin{tabular}{|l|l|c|c|}
\hline No. & Alternatif & V & Rangking \\
\hline 1. & Nicky & 0,6990 & 1 \\
\hline 2. & Mulyana & 0,6990 & 2 \\
\hline 3. & Ardi Faisal & 0,5732 & 3 \\
\hline 4. & Annas Rifai & 0,4289 & 4 \\
\hline 5. & Nurhidayat & 0 & 5 \\
\hline
\end{tabular}

Berdasarkan hasil perhitungan menggunakan metode AHP dan TOPSIS, didapati untuk yang menempati urutan pertama direkomendasikan yaitu Nicky yang memiliki nilai preferensi tertiggi dengan nilai 0,699, kemudian di urutan kedua ada Ardi Faisal yang memiliki nilai preferensi 0.5732 dan diurutan terakhir nurhidayat dengan nilai preferensi 0 .

\subsection{Perancangan dan Pengujian Sistem}

Perancangan sistem pendukung keputusan penentuan dosen terbaik untuk mendapatkan hasil layak atau tidak mengajar kembali di semester berikutnya setelah dilakukan analisis dan telah disetujui oleh pihak kampus Akademi Teknologi Bogor.

\subsubsection{Perancangan Sistem}

4.6.1.1 Diagram Use Case

Diagram use case adalah teknik untuk merekam persyaratan fungsional sebuah sistem. Use case mendeskripsikan interaksi antara pengguna sistem dengan sistem itu sendiri. Berikut adalah diagram use case pada penelitian ini 


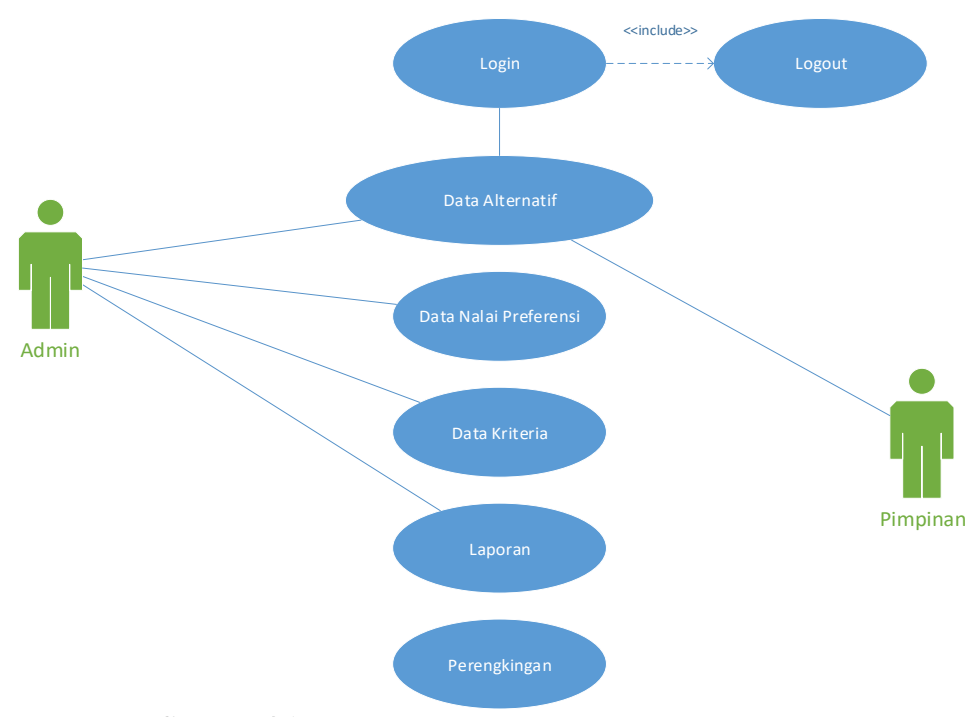

Gambar 4.1 Use Case Diagram Sistem Secara Keseluruhan

\subsubsection{Class Diagram}

Class diagram sistem ini memiliki lima tabel yaitu, alternatif, kriteria, nilai, pengguna, rangking. Masing-masing tantuk rubel memliki judul kolom (field) ruang data, karenanya setiap field ber-size (panjang karakter) dan ber- datatype (tipe data), di antara fieldada yang berstatus primary key untuk relasi antar tabel (table relation).

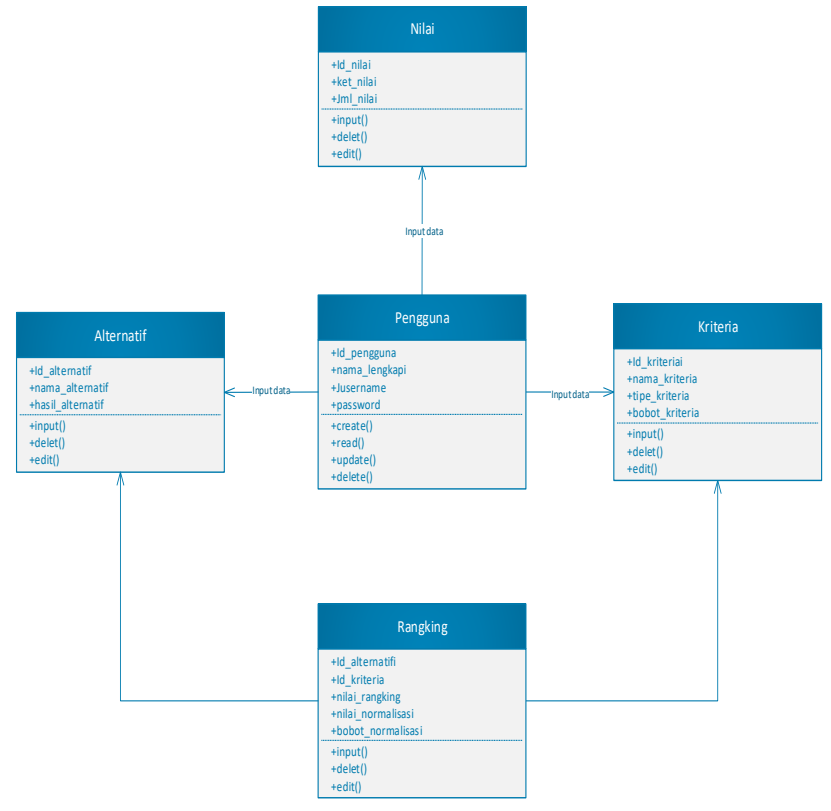

Gambar 4.3 Class Diagram

\subsection{Rancangan Layar}

Berikut adalah tampilan layar program yang dibuat menggunakan PHP dan database MySQL untuk sistem pendukung keputusan Penilaian Proses Belajar di Akademi Teknologi Bogor.

4.7.1 Tampilan Layar Login

Tampilan menu login digunakan agar kita mendapatkan akses untuk menjalankan menu - menu yang ada pada menu utama. Hal ini dilakukan supaya tidak sembarang orang dapat mengakses aplikasi ini. Sehingga dalam form menu kerahasiannya tetap terjaga dengan baik. Dilengkapi dengan tingkatan level user yaitu yang pertama user yaitu dapat mengakses semua menu dalam sistem tersebut, dan yang kedua yaitu manager hanya dapat mengakses menu perhitungan dan print laporan di sistem tersebut.

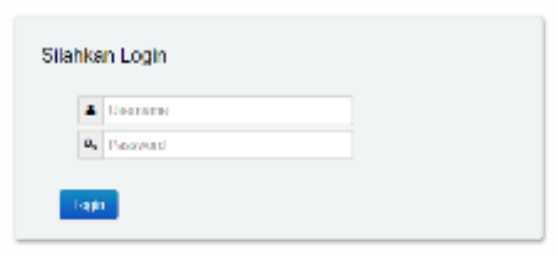

Gambar 4.3 Tampilan Layar Login 


\subsubsection{Tampilan Layar Menu Utama}

Gambar dibawah menampilkan tampilan menu utama pada aplikasi pertama kali dilakukan login. Pada layar menu utama tersedia menu bar yang terdiri dari menu kriteria, alternatif, perhitungan, password, dan logout.

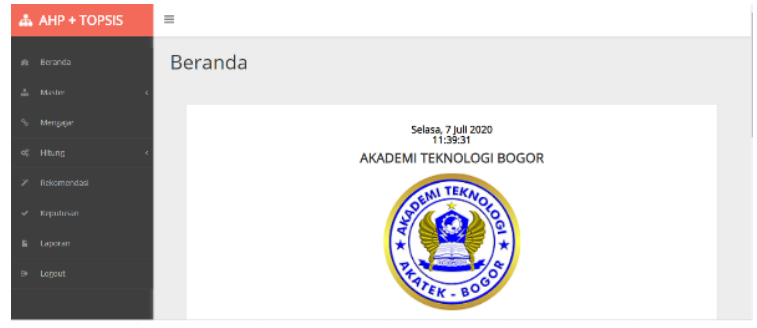

\subsubsection{Tampilan Layar Data Kriteria}

Gambar 4.4 Tampilan Layar Menu Utama

Tampilan layar data kriteria ini merupakan data kriteria yang digunakan pada penelitian ini yang telah ditentukan. Kurikulum, Perangkat Pembelajaran, Materi Bahan Ajar, Metode Pembelajaran dan Kehadiran Dosen.

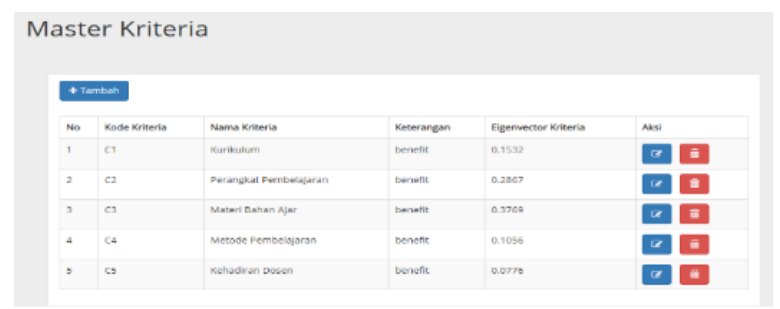

\subsubsection{Tampilan Layar Penilaian Bobot Kriteria}

Tampilan ini digunakan untuk menentukan tingkat kepentingan kriteria yang dapat diisi oleh Direktur selaku pemegang keputusan dalam kampus.

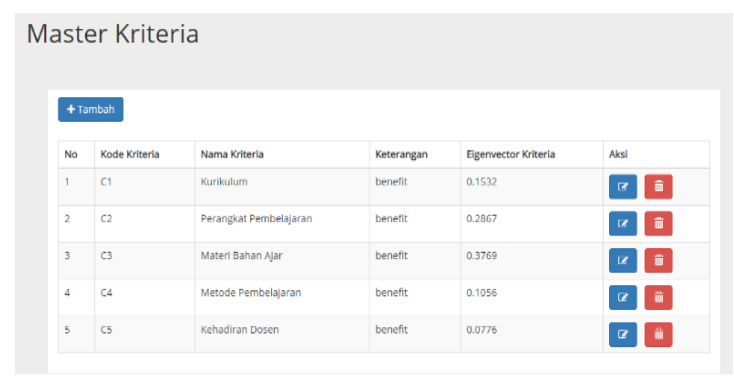

Gambar 4.6 Tampilan Layar Penilaian Bobot Kriteria

\subsubsection{Tampilan Layar Nilai Bobot Alternatif}

Merupakan tampilan dari nilai bobot masing-masing alternatif pada setiap kriteria. Nilai bobot ini didapat dari keterangan para ahli dan juga berdasarkan data yang ada di lapangan.

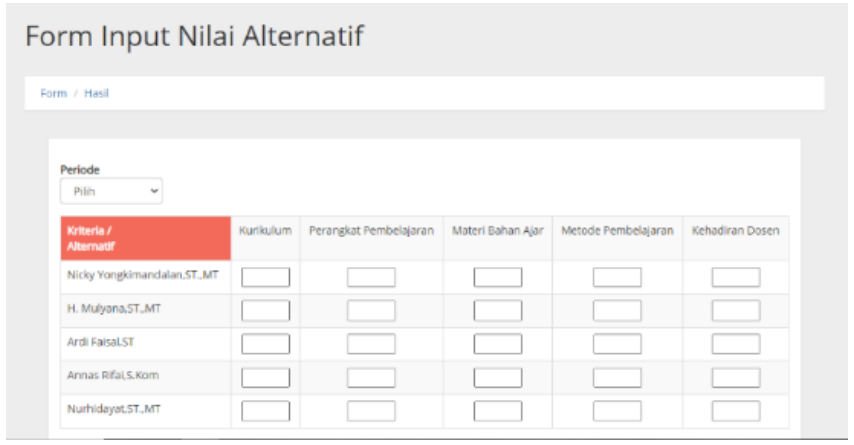

Gambar 4.7 Tampilan Nilai Bobot Alternatif

\subsubsection{Tampilan Matriks Bobot Prioritas Kriteria}

Merupakan tampilan matriks untuk bobot prioritas masing-masing kriteria beserta dengan nilai kekonsistensian data yang akan menentukan apakah data dapat diterima atau tidak berdasarkan dari nilai CR. Jika nilai CR kurang dari 0,1 maka data dapat diterima. 


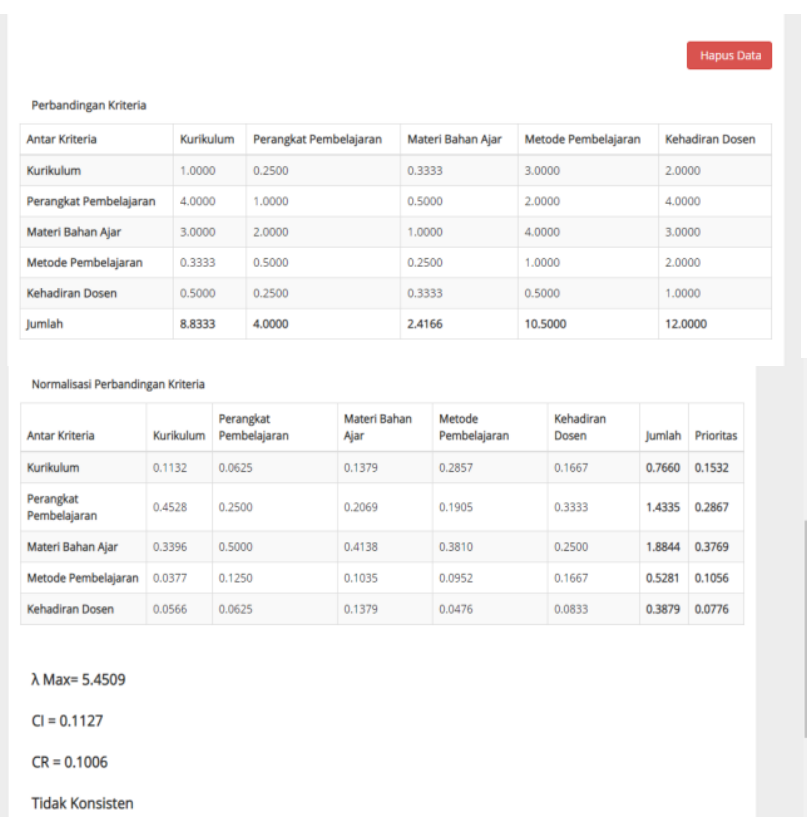

Gambar 4.8 Tampilan Matriks Bobot Prioritas Kriteria

\subsubsection{Tampilan Normalisasi Terbobot}

Merupakan tampilan dari hasil normalisasi menggunakan metode TOPSIS yang didapat dari perkalian matriks normalisasi dengan bobot prioritas yang sebelumnya telah didapat menggunakan metode AHP.

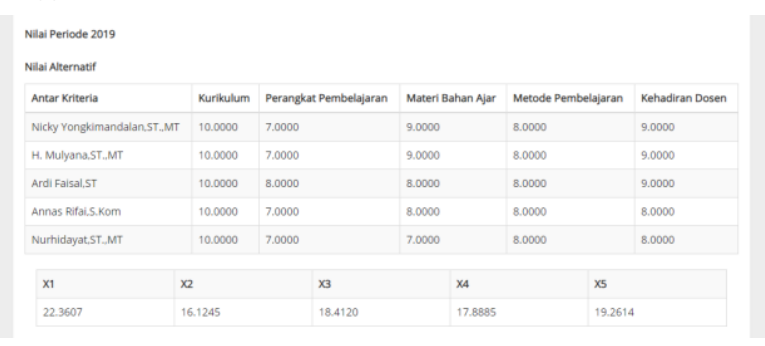

Gambar 4.9 Tampilan Normalisasi Dosen Terbobot

\subsubsection{Tampilan Matriks Solusi Ideal}

Merupakan tampilan dari matriks solusi ideal positif dan solusi ideal negatif menggunakan metode TOPSIS.

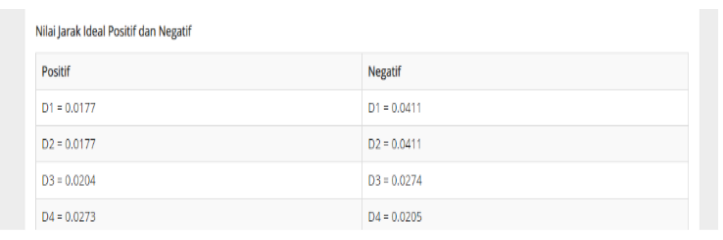

Gambar 4.10 Tampilan Matriks Solusi Ideal

\subsubsection{Tampilan Jarak Solusi dan Nilai Prefensi}

Merupakan tampilan jarak solusi ideal positif dan solusi ideal negatif, serta nilai preferensi yang didapatkan dari nilai jarak solusi ideal negatif dibagi dengan jumlah nilai jarak solusi ideal negatif ditambah jumlah nilai jarak solusi ideal positif.

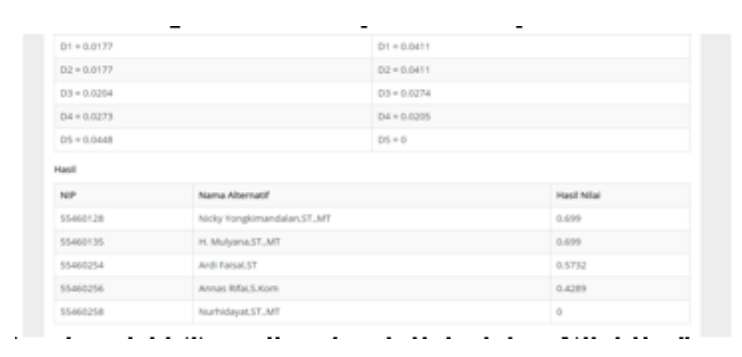

Gambar 4.11 Tampilan Jarak Solusi dan Nilai Preferensi 


\subsubsection{Tampilan Hasil Ranking}

Merupakan tampilan hasil akhir berupa ranking Penilaian Dosen terbaik yang nantinya akan dipilih untuk menjadi rekomendasi mengajar di semester.

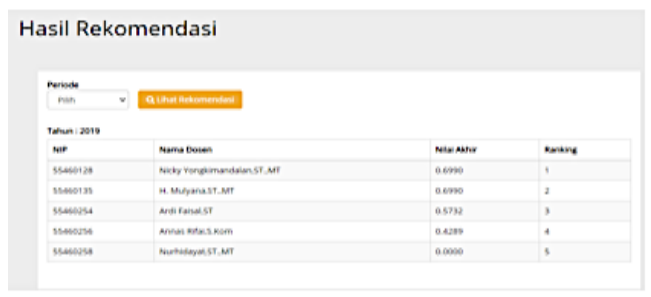

Gambar 4.12 Tampilan Hasil Ranking

\subsection{Pengujian Aplikasi}

Pengujian aplikasi ini menggunakan pengujian pembandingan (black box) Aplikasi dinyatakan berhasil melewati pengujian apabila dalam percobaan-percobaan berikut aplikasi tidak menjadi error. Pada metode pengujian black box, aplikasi diberikan berbagai macam kondisi masukan, kemudian keluaran yang dihasilkan sistem dibandingkan dengan keluaran yang diharapkan.

4.9. Pengujian UAT (User Acceptance Test)

Pengujian User Acceptance Test (UAT) yang dilakukan di Akademi Teknologi Bogor adalah memberikan hak kepada para pemegang kepentingan untuk langsung memberikan penilaian terhadap aplikasi sistem pendukung keputusan Penentuan Dosen Terbaik berupa kuesioner. Jumlah Responden adalah 4 orang dengan 6 pertanyaan.

Kategori Penilaian yang digunakan untuk kuesioner antara lain:

1. Tidak Sesuai (TS)

2. Sesuai $(\mathrm{S})$

3. Sangat Sesuai (SS)

\subsection{Implikasi Penelitian}

Dari hasil pengujian diatas dapat diambil berbagai implikasi penelitian dilihat dari aspek sistem, aspek manajerial maupun aspek penelitian lanjutan.

\subsubsection{Aspek Sistem}

Untuk menerapkan hasil penelitian ini dibutuhkan dukungan sistem yang baik sehingga pihak yang berkepentingan dapat menggunakan hasil penelitian ini untuk pengambilan keputusan. Oleh karena itu dibutuhkan sarana dan prasarana yang memadai yang terdiri dari hardware, software agar pengambilan keputusan pemilihan asuransi kesehatan dapat berjalan baik dengan sebuah sistem terkomputerisasi yang akan dibangun sesuai dengan hasil dari penelitian dan analisa penulis.

\subsubsection{Aspek Manajerial}

Hasil penelitian yang sudah diterapkan nantinya akan menciptakan kebijakan baru lagi dalam memilih dosen terbaik, dimana sebelumnya belum ada perhitungan dengan metode tertentu untuk menentukan dosen terbaik. Oleh karena itu akan dibutuhkan juga sumber daya manusia yang mengerti tentang penggunaan komputer. Sehingga diperlukan adanya pelatihan dan sosialisasi terhadap penerapan sistem baru.

\subsubsection{Aspek Penelitian Lanjutan}

Penelitian lanjutan dapat dilakukan untuk kajian studi yang serupa. Penelitian ini dapat dikembangkan dengan penggabungan metode lain, seperti metode fuzzy. Selain itu penelitian juga dapat mengikuti perkembangan sistem yang semakin lama akan semakin berkembang, dapat juga digunakan metode yang sama untuk proses sistem yang lain.

4.11 Rencana Implementasi

Setelah dilakukan penelitian untuk penentuan dosen terbaik dengan menggunakan metode AHP dan TOPSIS pada Akademi Teknologi Bogor, selanjutnya akan dirancang rencana implementasi.

\section{Kesimpulan}

\subsection{Kesimpulan}

Setelah melakukan analisa, perancangan dan pengujian maka dapat diperoleh kesimpulan sebagai berikut :

1. Sistem model keputusan pendukung penentuan dosen terbaik yang dibangun dapat membantu Akademi Teknologi Bogor, sebagai gambaran dalam pengambilan keputusan untuk mendapatkan dosen terbaik. Sistem pendukung keputusan dibangun untuk mempercepat pemilihan penentuan dosen terbaik.

2. Sistem Pendukung Keputusan penentuan dosen terbaik mampu menangani pengolahan data.

3. Sistem dengan menggunakan metode AHP dan TOPSIS dapat membantu perhitungan yang sesuai dengan kebutuhan, yaitu menentukan dosen terbaik diantara dosen yanga ada di Akademi Teknologi Bogor. Dimana nilai terbesar adalah rangking pertama yang diperoleh Bapak Nicky Yongkimandalan,ST.,MT sebesar 0.70, rangking kedua diperoleh Bapak H. Mulyana,ST.,MT 0,69 dan pada rangking ketiga diperoleh Bapak Ardi Faisal,ST 0.57 .

\subsection{Saran}

Dengan demikian setelah dilakukan penelitian dan dapat dapat disimpulkan diatas maka adanya saran untuk kedepannya, yaitu:

1. Agar sistem ini dikembangkan lebih lanjut dengan menggunakan data yang lebih besar sehingga aplikasi ini dapat digunakan sebagai salah satu cara dalam pengambilan keputusan untuk menjadi lebih akurat dan berguna.

2. Agar sistem ini dapat mempermudah kerja bagian akademik untuk menentukan dosen terbaik dan kedepannya bisa diintegrasikan ke dalam sistem akademik kampus di Akademi Teknologi Bogor.

\section{Daftar Pustaka}

[1] Davis, Ralp C dan Hasan; (2014) “Pokok-Pokok Materi Teori Pengambilan Keputusan.” Jakarta: Grahalia Indonesia.

[2] Diana. (2018) "Metode \& Aplikasi Sistem Pendukung Keputusan.” Yogyakarta: Deepbulish Budi Utama.

[3] Faesal Andris, Silmi Fauziati,Dkk. (2015) "Dss Untuk Penilaian Dosen Dengan Metode AHP dan TOPSIS." Jurnal Ilmiah Sematik UGM. Kemenristek. (2015). Buku Pedoman Sertifikasi Pendidik Untuk Dosen (SERDOS) Terintegrasi. Jakarta: Direktorat Jendral Pendidikan Kementrian Pendidikan dan Kebudayaan.

[4] Kusrini. (2017) "Konsep dan Aplikasi Sistem Pendukung Keputusan ." Yogyakarta: Ansi.

[5] Kusumadewi, S., Hartati, S., Harjoko, A. dan Wardoyo, R. (2006) “Fuzzy Multi-Atribute Decision Making (Fuzzy MADM).” Yogyakarta: Graha Ilmu.

[6] Kusumadewi, Sri. (2016) “Analisis Desain Sistem Fuzzy Menggunakan Tool Box Matlab.” Yogyakarta: Graha Ilmu.

[7] Kusumadewi, Sri dan Hari Purnomo. (2016) "Aplikasi Logika Fuzzy Untuk Pendukung Keputusan." Yogyakarta: Graha Ilmu

[8] Moore, J.H and M.G. Chang. (2015) "Design of Decision Support System." Database 12(1-2). 
[9] Nofriansyah dan Devid. (2017) "Multi Criteria Decision Making (MCDM) Pada Sistem Pendukung Keputusan." Yogyakarta: Deepublish Budi Utama.

[10] Novian, Dian. (2015) "Perbandingan Gabungan Metode AHP dengan Metode TOPSIS Dalam Penerima Beasiswa,"

[11] Purbaratri, Winny. (2018) "Penentuan Dosen Terbaik Menggunakan Metode AHP dan TOPSIS (Studi Kasus: STMIK Insan Pembangunan Tangerang)."

[12] Puspitasari. W.D dan Ilmi, D.K. (2016) "Sistem Pendukung Keputusan Pemilihan Dosen Berprestasi Menggunakan Metode Analytical Hierarchy Process (AHP)."

[13] Rahman, E.F et Al. (2017) "Decision Support Systems for Performance and Evaluation of Teacher in General-English Course by Using the SMARTER and TOPSIS Methods, IOP Conference Series: Materials Science and Engineering."

[14] Simanjorang, R. Mahdalena. Medan. (2019) "Sistem Pendukung Keputusan Menentukan Efektifitas Pembelajaran Metodologi Penelitian Sistem Informasi di STMIK Pringsewu dengan Metode Analytical Hierarchy Process (AHP)."

[15] Sofhian,Dkk. (2016) "Sistem Pendukung Keputusan Pemilihan Dosen Terbaik Menggunakan Metode Promethee (Studi Kasus: Teknik Informatika)." Yogyakarta: Graha Ilmu.

[16] Sugiono. (2016) "Metode penelitian Administrasi." Bandung: Pusat Bahasa Depdiknas.

[17] Sumiati dan Nuryadin. (2013) "Sistem Pendukung Keputusan dalam menentukan Penilaian Kinerja Dosen dengan Menggunakan Metode Fuzzy Database Model Mamdani."

[18] Turban, E. (2005) "Decision Support System and Intelligent System,” Jakarta: Andi Publisher. 